\title{
Desa Membangun UMKM: \\ Pendampingan UMKM berbasis Village-Driven Development dalam Penguatan Ekonomi Warga Di Desa Gogodeso Kecamatan Kanigoro Kabupaten Blitar
}

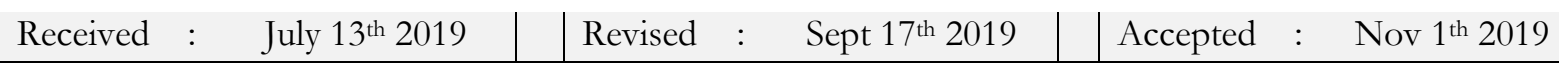

\author{
Luhung Achmad Perguna, Imamul Huda Al Siddiq, Irawan \\ Jurusan Sosiologi Fakultas Ilmu Sosial Universitas Negeri Malang \\ luhung.fis@um.ac.id,imamul.huda.fis@um.ac.id, irawan.fis@um.ac.id
}

\begin{abstract}
Village dignity is evident from the efforts of the village to mobilize all of its resources, including in strengthening the Micro Small Medium Enterprise (MSMEs) sector. Strengthening MSMEs becomes important as an economic asset of the village, while at the same time reducing rural and urban inequality. This effort continues to be carried out and endeavored by the village of Gogodeso, Kanigoro sub-district, Blitar district. Since because they are aware of its great potential, unfortunately it has not been optimized. The vision of building a village changes. With the facilitation from team, it is optimized by first analyzing the potential situation of MSMEs through the Participatory Rural Appraisal approach based on Village-Driven Development, which means that it requires the active involvement of all village stakeholders. Followed by the alignment of vision and mission through the Building Village Workshop and finally through assistance in marketing through packaging branding as part of the problems of SMEs so far. These three steps are part of an effort to turn Gogodesa village into the MSME Goddess (MSMEbased Tourism Village). The result is that the community who initially wanted to build an agriculture-based village changed and agreed to build an MSME-based village.
\end{abstract}

Keyword: Micro Small Medium Enterprise (MSMEs), Village-Drven Development, Community Economic Development.

\section{Pendahuluan}

Desa Gogodeso dewasa ini sedang gencar mengembangkan UMKM untuk meningkatkan taraf perekonomian masyarakat. Jumlah UMKM di desa Gogodeso lebih dari 20 UMKM yang tersebar di ketiga dusun dengan ragam kategorisasi. Mulai dari yang berkembang pesat, mati segan hidup tak mau hingga keberadaan UMKM seperti ketiadaannya. Kondisi UMKM yang beranekaragam tersebut mengindikasikan bahwa pemerintah desa belum mampu untuk mengembangkan UMKM secara baik. Mengingat mata pencarian penduduk di desa ini adalah bertani dan berkebun, inisiasi atas pengembangan UMKM seperti kurang berarti. Lahan pertanian dan perkebunan yang cukup luas belum dimanfaatkan secara optimal karena memang keterbatasan keahlian pada sumber daya manusianya. Aksesibilitas desa yang tidak terlalu jauh dari kantor kecamatan dan pendopo kabupaten, sayangnya tidak berkorelasi terhadap kemajuan UMKM Desa. 
Padahal di desa ini cukup dikenal sebagai desa yang memiliki jumlah UMKM yang relatif banyak dibandingkan desa lain di Kabupaten Blitar.

Sebagaimana telah diketahui bersama, sektor Usaha Mikro Kecil Menengah (UMKM) merupakan salah satu pilar pada perekonomian nasional. ${ }^{1}$ UMKM sendiri merupakan unit usaha produktif yang berdiri sendiri yang dilakukan oleh orang-perorangan atau Badan usaha di semua sektor ekonomi ${ }^{2}$. Sektor UMKM berbeda dengan sektor informal meski memiliki beberapa kesamaan. Salah satu kesamaannya yang jelas nampak adalah, keberadaan dan kelangsungan keduanya dalam sistem ekonomi kontemporer bukanlah gejala negatif, namun justru berperan dalam pemerataan pendapatan dan memberikan sumbangsih terhadap kemajuan perekonomian bangsa $^{3}$. Pertumbuhan UMKM yang signifikan diharapkan juga dapat menyerap tenaga kerja dan meningkatkan keahlian masyarakat setempat terlebih di aras lokal. Bila ini terjadi, maka UMKM telah banyak membantu pemerintah dalam menyelesaikan permasalahan pengangguran, mengurangi angka kemiskinan, memperluas lapangan pekerjaan, dan pada gilirannya akan meningkatkan pendapatan masyarakat. ${ }^{4}$ UMKM juga membantu masyarakat yang terjerat Rentenir. $^{5}$

Meskipun UMKM sudah diakui memiliki peran strategis sayangnya sektor ini belum berkembang secara signifikan dan belum berjalan sesuai yang diharapkan. Banyak permasalahan umum yang dihadapi UMKM di Indonesia dalam pengembangan usahanya antara lain adalah (1) terbatasnya pendanaan untuk pengembangan usaha; (2) kurangnya informasi dan akses bahan baku dan pasar; (3) rendahnya kualitas sumber daya manusia; (4) rendahnya kemampuan untuk menghasilkan produk yang inovatif; dan (5) lemahnya pendampingan ${ }^{6}$. Hal ini senada dengan yang diungkapkan oleh Berry yang menyatakan tiga alasan mendasar Negara berkembang memandang penting keberadaan UMKM, yang pertama adalah kinerja UMKM lebih baik dalam hal menghasilkan tenaga kerja, yang kedua yakni UMKM sering mencapai peningkatan

${ }^{1}$ Ragimun Sudaryanto dan Rahma Rina Wijayanti, "Strategi Pemberdayaan Umkm Menghadapi Pasar Bebas Asean,” Pusat Kebijakan Ekonomi Makro. Badan Kebijakan Fiskal. Kementerian Kenangan, Jakarta, 2013.

2 Tahi Hamonangan Tambunan Tulus, "Development of small and medium enterprises in a developing country," ed. oleh Kevin McKague dkk., Journal of Enterprising Communities: People and Places in the Global Economy 5, no. 1 (1 Januari 2011): 68-82, https://doi.org/10.1108/17506201111119626.

3 Rachmawan Budiarto dkk., Pengembangan UMKM Antara Konseptual dan Pengalaman Praktis (UGM PRESS, 2018).

${ }^{4}$ P. Eko Prasetyo, "Peran Usaha Mikro Kecil Dan Menengah (UMKM) Dalam Kebijakan Penanggulangan Kemiskinan Dan Pengangguran," Akmenika Upy 2, no. 1 (2008): p1-13.

5 Ainna Amalia FN dan Lilis Rahmawati, "Pendampingan Manajemen Keuangan Melalui Program Literasi Keuangan Kepada Komunitas Usaha Mikro Kecil dan Menengah (UMKM) yang Terjerat Rentenir di Kabupaten Nganjuk," Engagement : Jurnal Pengabdian Kepada Masyarakat 3, no. 1 SE-Articles (30 Mei 2019), https://doi.org/10.29062/engagement.v3i1.55.

${ }^{6}$ Rokhani Hasbullah dkk., "Model pendampingan UMKM pangan melalui inkubator bisnis perguruan tinggi," Jurnal ilmu Pertanian indonesia 19, no. 1 (2014): 43-49. 
produktivitasnya melalui investasi dan perubahan teknologi, dan yang ketiga yaitu diyakini UMKM memiliki keunggulan pada fleksibilitas ketimbang usaha besar? ${ }^{7}$

Desa Gogodeso saat ini sedang genacar melakukan pengembangan terhadap UMKM yang ada di daerahnya baik itu yang sudah mapan, maupun yang belum mampu berdiri secara tegak. Beberapa usaha yang relatif dikenal di kabupaten Blitar sebut saja misal UMKM Kalimasada yang sering meraih penghargaan dari pemerintah seperti dari Kementerian Perdagangan dengan penghargaan terbaik One Village One Product di kabupaten Blitar adalah salah satu UMKM yang telah mapan di desa tersebut. Terpilihanya UMKM ini selain soal citarasa pada makanannya, yang tak kalah penting adalah pelibatan masyarakat sekitar sebagai tenaga utamanya pada saat musim lebaran, natal dan tahun baru. UMKM Kalimasada bahkan pernah pula meraih penghargaan dari Presiden SBY kala itu. Selain Kalimasada, terdapat pula UMKM Annisa Jaya dan Amika Jaya yang usahanya juga berkembang pesat dengan produknya aneka keripik mulai dari pisang, usus, bawang, pepaya hingga dodol aneka buah. Sayangnya kemajuan UMKM ini tidak diikuti oleh UMKM yang lain yang berada di desa Gogodeso, mereka ada yang mati suri, hidup segan mati tak mau, hingga laku pada saat musim-musim tertentu, selebihnya mati. Ada banyak ragam sebab kenapa UMKM yang lain belum bisa berkembang dengan pesat. Paling tidak berdasar hasil identifikasi ada dua hal penting permasalahan di desa Gogodeso yaitu: (1) supporting system dari pemerintah Desa utamanya visi desa yang masih kabur; dan (2) nadirnya pendampingan yang dilakukan baik oleh pihak internal maupun eksternal. Pengabdian ini hadir sebagai bagian dari pendampingan yang dilakukan secara intens untuk mengatasi kedua persoalan tersebut dengan dukungan Pemerintah Desa dan masyarakat setempat. Tanpa dukungan masyarakat setempat, maka keinginan mewujudkan masyarakat Desa Gogodeso yang lebih berdaya dan mandiri melalui UMKM akan mustahil tercapai.

\section{Metode}

Pada umumnya program pendampingan, pengabdian dan pembangunan mendekati masyarakat dengan program yang telah dibuat oleh tim eksternal. Meski ini baik dan berdasar analisis pada situasi masyarakat setempat, banyak kelemahan melalui pendekatan ini. Diantaranya agen pengembangan dan pembangunan tidak mengerti karakteristik budaya lokal, seperti praktik budaya dan nilai lokal. Juga biasanya rencana dan kegiatan yagn diambil tidak memiliki dukungan dari semua anggota komunitas. Yang tak kalah penting, masyarakat pengguna kurang mengerti

7 Albert Berry, Edgard Rodriguez, dan Henry Sandee, "Small and medium enterprise dynamics in Indonesia," Bulletin of Indonesian Economic Studies 37, no. 3 (2001): 363-84.

Volume 3, Number 2, November 2019| 219

Desa Membangun UMKM: Pendampingan UMKM dalam Pembangunan Ekonomi Desa di desa Gogodeso 


\section{ENGAGEMENT}

Lurnal Pengabdian Kepada Masyarakat

ISSN : 2579-8375 (Print)

ISSN : 2579-8391 (Online)
This work is licensed under a Creative Commons Attribution-ShareAlike 4.0 International License.

CC BY SA

dasar untuk kegiatan yang direncanakan ${ }^{8}$. Dari kelemahan inilah, PRA (Participatory Rural Appraisal ${ }^{9}$ menjadi jawaban dalam mengatasi persoalan tersebut. Agar PRA berjalan efektif, maka diperlukan tiga pilar dalam PRA yaitu komunikasi yang efektif dan terampil disertai dengan etika yang baik, dan pelibatan partisipasi aktif dari masyarakat setempat, dan hubungan interpersonal yang baik ${ }^{10}$. Pendekatan PRA menekankan bahwa masyarakat berdaya sekaligus memiliki kemampuan untuk melakukan kontrol dan berkehendak terhadap program yang ada. Masyarakat merupakan subjek sekaligus objek pembangunan yang bisa berkehendak. Ketiga hal ini terus menerus dilakukan untuk mengurai setiap permasalahan terkait penguatan UMKM desa Gogodeso.

Pendampingan UMKM ini dilakukan dalam beberapa tahap yang antara lain, tahap pertama yang dilakukan oleh tim pengabdian adalah dengan melakukan analisis situasi dengan fokus pada kondisi UMKM yang ada di desa Gogodeso pada penguatan ekonomi sekaligus peran pemerintah desa dalam penguatan UMKM. Analisis ini dilakukan melalui observasi dan wawancara yang dilakukan dengan cara ngopi bareng, kunjungan door to door dengan waktu yang telah disepakati agar tidak menggangu aktivitas utama baik dengan perangkat desa maupun pelaku UMKM seperti Kalimasada, Amika Jaya, Annisa Jaya, Jenang, Stik Sawi, Sambel Pecel dan beberapa UMKM lainnya dengan didampingi masyarakat setempat. Wawancara dan observasi dilakukan sebagai dasar dalam melakukan analisis situasi. Analisis ini penting dilakukan sebagai landasan dalam membangun kegiatan sarasehan bersama seluruh elemen masyarakat. Kelemahan dan ancaman coba diminimalisir dengan penguatan pada kekuatan dan potensi yang ada di desa Gogodeso.

Pasca analisis situasi pada masyarakat Gogodeso, yang dilakukan oleh tim pengabdian dengan fasilitasi dari pemerintah desa adalah dengan melakukan Sarasehan Desa yang mengambil tajuk "Desa membangun UMKM". Sarasehan ini dilakukan dalam upaya membangun visi dan misi bersama agar memiliki persepsi yang sama. Pada saat yang sama juga membangun kesadaran masyarakat akan arti penting penguatan ekonomi desa melalui UMKM. Bahwa UMKM merupakan pilar perekonomian desa yang pada gilirannya akan mengangkat pendapatan dan pertumbuhan desa.Setelah memiliki visi yang sama, tahap berikutnya adalah bersama-sama pemerintah desa melakukan pendampingan UMKM khususnya dalam pemasaran. Pendampingan ini sebagai cara

\footnotetext{
${ }^{8}$ Mohd Yusof Hj Abdullah dkk., "Participatory Rural Appraisal (PRA): An Analysis of Experience in Darmareja," Akademika 82, no. 1 (2012).

${ }^{9}$ Robert Chambers, "The Origins and Practice of Participatory Rural Appraisal," World development 22, no. 7 (1994): 953-969.

10 Nammmalvar Narayanasamy, Participatory rural appraisal: Principles, methods and application (SAGE Publications India, 2009).
} 


\section{ENGAGEMENT}

Lurnal Pengabdian Kepada Masyarakat

ISSN : 2579-8375 (Print)

ISSN : 2579-8391 (Online)
This work is licensed under a Creative Commons

Attribution-ShareAlike 4.0 International License.

CC BY SA

untuk memahami sekaligus menggali hal yang perlu dan bisa ditingkatkan dan didampingi. Persoalan visi desa dan juga modal dari pemerintah Desa menjadi kunci dalam penguatan UMKM ini. $^{11}$

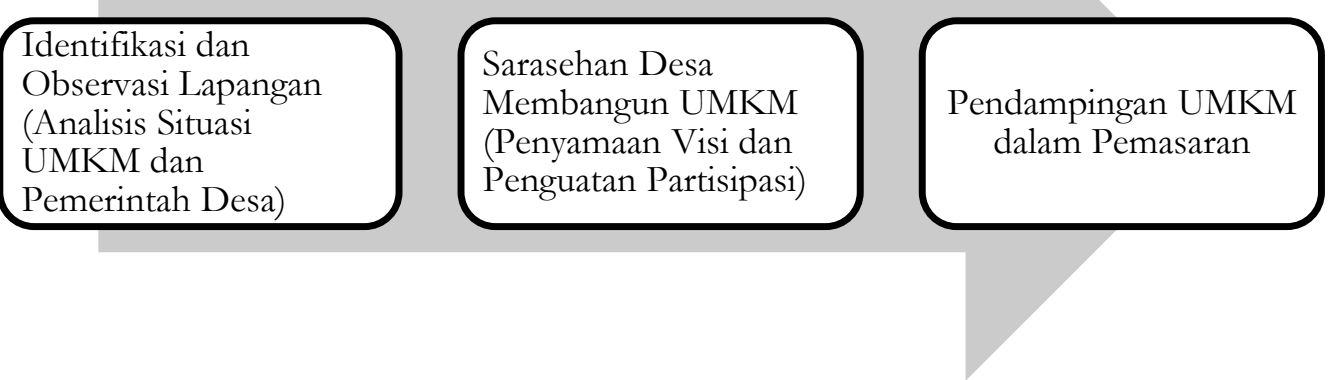

\section{Gambar 1. Metode Pendampingan Penyelesaian Masalah berbasis Village-Driven Development}

\section{Hasil dan Diskusi}

\section{Identifikasi Permasalahan dalam Perspektif Lokal}

Persoalan yang terjadi di masyarakat tidak hanya perlu diketahui melalui perspektif eksternal atau dari pihak ketiga tetapi juga perlu diupayakan untuk self reflection atau mengenali potensi diri ${ }^{\mathbf{1 2}}$. Pengenalan potensi atau permasalahan diri secara mandiri harus dilakukan dan diupayakan karena merupakan langkah awal yang baik dan produktif bagi masyarakat. Kesadaran ini penting dalam melihat diri dan lingkungannya secara kritis karena merupakan bekal dasar untuk membangun sense of belonging sekaligus sebagai bekal dalam menguatkan perekonomian desa melalui UMKM. Perguruan Tinggi dalam hal ini tim pengabdian sebagai pihak eksternal memantik dan memfasilitiasi upaya refleksi diri tersebut. Pelaku UMKM dan perangkat desa diajak bersama tim dari Perguruan Tinggi secara kritis untuk mengali dan mengidentifikasi berbagai permasalahan secara internal dan eksternal.

Dari penelusuran awal tim pengabdian diperoleh ragam persoalan yang diringkas menjadi dua aspek yaitu aspek internal dan aspek eksternal. Permasalahan ini digali dari pengalaman nyata masyarakat dengan didampingi oleh tim pengabdian. Harus diakui pada kenyataannya tidak mudah

\footnotetext{
${ }^{11}$ Kajian terkait pemberdayaan Desa, bisa juga dibaca Abdur Rozaki dan Siti Rohaya, "Memberdayakan Desa Melalui Pariwisata Berbasis BUMDES ," Engagement :Jurnal Pengabdian Kepada Masyarakat 3, no. 1 SE-Articles (30 Mei 2019), https://doi.org/10.29062/engagement.v3i1.46. Lihat juga FN dan Rahmawati, "Pendampingan Manajemen Keuangan Melalui Program Literasi Keuangan Kepada Komunitas Usaha Mikro Kecil dan Menengah (UMKM) yang Terjerat Rentenir di Kabupaten Nganjuk."

12 Vina Salviana Darvina Soedarwo, "Pemberdayaan Masyarakat Melalui Pendidikan Nonformal Berbasis Potensi Lokal dalam Membangun Desa Wisata Adat," Jurnal Sosiologi Pendidikan Humanis 2, no. 2 (2017): 96-102.
} 


\section{ENGAGEMENT}

Lurnal Pengabdian Kepada Masyarakat

ISSN : 2579-8375 (Print)

ISSN : 2579-8391 (Online)
This work is licensed under a Creative Commons Attribution-ShareAlike 4.0 International License.

CC BY SA

untuk membangun dan menguatkan UMKM. Perlu adanya suatu upaya untuk menciptakan dan merekayasa agar UMKM terus bergerak dan menguat dalam rangka kemandirian desa. Keinginan memajukan UMKM harus dibarengi dengan semangat membangun desa bersama. Dengan identifikasi ini, harapannya menjadikan langkah yang dilakukan oleh desa utamanya dan tim eksternal menjadi lebih terarah.

Terdapat beberapa aspek yang di dalamnya ditemukan beberapa permasalahan mendasar dalam upaya pengembangan UMKM. Secara internal, permasalahan yang dihadapi adalah permasalahan kelembagaan, kualitas sumber daya manusia, dan persoalan infrastruktur. Sedangkan dalam aspek eksternal permasalahan yang dapat diidentifikasi adalah pemasalahan kelembagaan dan infrastruktur. Permasalahan kelembagaan dan infrastruktur menjadi tantangan tersendiri bagi tim pengabdian maupun pemerintah desa. Secara internal permasalahan kelembagaan yang ada adalah visi misi desa yang belum terarah. Visi misi seyogyanya tidak hanya sekedar hitam di atas putih yang sulit untuk diimplementasikan. Secara kelembagaan pemerintah desa harus memiliki target target yang jelas kapan visi misi tersebut dapat terwujud. Sedangkan secara eksternal permasalahan kelembagaan pesaing sejenis sudah cukup banyak. Sehingga UMKM maupun pemerintah desa harus memiliki strategi khusu agar mampu menembus peluang pasar.

Permasalahan selanjutnya adalah permasalahan infrastruktur baik secara internal maupun eksternal. Terbatasnya modal serta akses informasi dan pasar yang terbatas di kalangan pelaku UMKM menjadi tantangan tersendiri. Akses informasi dan pasar harus diperluas baik itu melalui pembangunan akses ataupun pembangunan sumber daya manusia yang siap menjawab tantangan revolusi industri 4.0. Revolusi industri tersebut mensyaratkan kemampuan digital menjadi prasyarat mutlak agar dapat bersaing.

\begin{tabular}{|l|l|l|}
\hline \multicolumn{2}{|l|}{ Aspek } & Masalah yang dihadapi \\
\hline \multirow{4}{*}{ Internal } & Kelembagaan & $\begin{array}{l}\text { Visi Desa membangun yang belum jelas dan } \\
\text { terarah }\end{array}$ \\
\cline { 2 - 3 } & Sumber Daya Manusia & $\begin{array}{l}\text { Kualitas Sumber Daya Manusia yang belum } \\
\text { mumpuni }\end{array}$ \\
\cline { 2 - 3 } Eksternal & Infrastruktur & Terbatasnya modal \\
\cline { 2 - 3 } & Kelembagaan & Pesaing sejenis cukup banyak \\
\hline \multirow{2}{*}{ Infrastruktur } & Akses informasi dan pasar yang terbatas \\
\hline
\end{tabular}

\section{Tabel 2 (Permasalah dalam UMKM)} Sumber : Diolah oleh Penulis

Dari permasalahan yang termaktub dengan ragam persoalan yang cukup banyak tersebut, permasalahan dikerucutkan oleh tim pengabdian dengan satu persoalan pokok dari ragam 
persoalan yang dihadapi. Persoalan tersebut tidak bisa diselesaikan dalam satu waktu secara bersama sehingga, tim bersama dengan tim desa mengerucutkan menjadi dua persoalan pokok. Desa dan tim pengabdian sepakat bahwa yang harus dicari solusi bersama yaitu belum jelasnya visi desa dalam membangun desa. Artinya selama ini desa berjalan tanpa atau tak sesuai dengan arah pembangunan. Di tahun tertentu fokus pada pertanian dalam upaya peningkatan dan pengentasan kemiskinan warga. Kemudian menginjak tahun berikutnya fokus diubah kepada pengembangan desa pertanian. Di tahun berikutnya fokus berubah lagi kepada pengembangan desa wisata berbasis pada UMKM. Artinya visi desa harus disusun bersama seluruh stakeholder. RPJMD (Rencana Pemerintah Jangka Menengah Desa) yang menjadi rujukan dari menjalankan setiap program pemerintah desa terkadang meleset dan tidak sesuai dengan apa yang termaktub dalam RPJMD. Persoalan kedua adalah belum adanya pendampingan secara intensif baik dari pihak internal maupun eksternal. Kedua persoalan ini dipecahkan melalui kegiatan sarasehan desa dan juga dilakukan dengan pendampingan.

\section{Sarasehan Desa untuk Membangun Visi dan Partisipasi}

Desa Gogodeso memiliki luas wilayah $\pm 300,390 \mathrm{ha} / \mathrm{m}^{2}$ yang dihuni oleh sekitar 5.367 jiwa penduduk yang mayoritas penduduknya bekerja sebagai petani. Wilayah desa Gogodeso termasuk wilayah dataran rendah dengan ketinggian sekitar 50m diatas permukaan laut. Desa ini juga merupakan desa dengan pasokan air yang cukup, artinya desa ini terdapat sumber air untuk pertanian yang sangat memadai dan juga curah hujan yang mendukung sehingga penduduk dapat memanen padi sebanyak dua kali dalam satu tahun. Hal ini menunjukan bahwa desa ini memiliki potensi yang besar pada pertanian dan perkebunan, bila ini dimanfaatkan dengan maksimal bukan mustahil sumber daya yang dahsyat untuk dikembangkan. Potensi lain yang tak kalah penting adalah desa ini memiliki satu tempat wisata yang cukup terkenal. Wisata tersebut adalah Bendungan Lodoyo yang terletak di dusun Serut. Bendungan ini merupakan salah satu pembangkit listrik tenaga air yang ada di Sungai Brantas. Bendungan ini banyak dikunjungi oleh masyarakat luar daerah untuk sekedar menikmati keindahan alam dan semilir angin bahkan memancing dan menyaksikan pagelaran budaya yang diadakan pada waktu tertentu.

Desa Gogodeso memiliki empat dusun yaitu dusun Gogodeso, dusun Ndogong, dusun Ngade, dan dusun Serut Dari keempat dusun tersebut hanya dusun Ndogong yang tidak memiliki UMKM selebihnya tersebar di ketiga dusun lainnya. Jumlah UMKM di desa Gogodeso lebih dari 20 UMKM yang tersebar di ketiga dusun dengan ragam kategorisasi. Dari yang berkembang pesat, mati segan hidup tak mau hingga keberadaan UMKM seperti ketiadaannya. Dengan banyaknya 
UMKM tersebut dengan segala tipologinya, maka hal yang dilakukan pertama oleh tim pengabdian selaku fasilitator adalah penyamaan visi-misi baik dengan pemerintah desa, tokoh masyarakat dan juga dengan UMKM yang ada di desa. Ini penting dilakukan dengan harapan seluruh stakeholder yang ada di desa Gogodeso memahami apa yang akan dilakukan kedepan dalam membangun desa. Penyamaan visi memiliki urgensi agar arah ekonomi dalam penguatan ekonomi desa lebih terarah dan terfokus. Banyak pembangunan desa yang selama ini dilakukan tanpa visi atau arah yang jelas. Hal ini terbukti melalui politik anggaran desa. Pembangunan infrastruktur desa memiliki porsi yang sangat besar dari total anggaran dengan angka yang nyaris menyentuh di 90 persen dibandingkan dengan pembangunan sumber daya manusia. Hal ini lumrah dilakukan karena bagi desa, pembangunan infrastruktur lebih nyata hasilnya dan mudah dalam melakukan pertanggungjawaban ketimbang fokus pada penguatan sumber daya manusia. Belum lagi bicara soal pelibatan dan partisipasi aktif seluruh stakeholder yang masih sangat minim. Maka, visi seperti gambaran masa depan ekonomi dalam membangun asa desa. Desa tak akan bisa berdaya dan bermartarbat tanpa bantuan seluruh elemen, namun bila seluruh elemen bersatu tanpa adanya visi yang jelas, yang terjadi desa berkembang tanpa arah yang pada gilirannya akan memunculkan konflik $^{13}$.

Setelah penyamaan visi agar lebih terarah, terukur dan juga tidak menimbulkan konflik, tahap berikutnya yang dilakukan adalah membangun partisipasi aktif seluruh elemen desa khususnya dalam membangun UMKM desa. Partisipasi masyarakat dalam proses pembangunan merupakan prasyarat yang akan melandasi berhasil tidaknya proses pembangunan ${ }^{14}$. Pembangunan yang efektif sekaligus tepat sasaran membutuhkan partisipasi pihak pemangku kepentingan karena mereka semualah yang akan terdampak secara langsung dalam proses pembangunan tersebut. Mereka tidak melulu dijadikan sebagai objek pembangunan yang selama ini terjadi atau hanya dijadikan komoditas politik sesaat. Tetapi juga seharusnya masyarakat harus dijadikan sebagai subjek pembangunan. Partisipasi masyarakat dalam pembangunan tidak hanya dipandang sebagai proses yang harus dilalui tetapi juga merupakan tujuan yang harus dicapai secara bersama. Kenapa tujuan? Karena salah satu indikator keberhasilan pembangunan adalah bilamana tingkat partisipasi masyarakat cukup tinggi dalam pembangunan. Maka dari itu, partisipasi dapat dimaknai ganda yaitu partisipasi sebagai alat untuk menyelenggarakan pembangunan dan sebagai tujuan dari

${ }^{13}$ Siti Ainul Wida, Djoko Supatmoko, dan Taufik Kurrohman, "Akuntabilitas Pengelolaan Alokasi Dana Desa (ADD) di Desa-Desa Kecamatan Rogojampi Kabupaten Banyuwangi," E-Journal Ekonomi Bisnis Dan Akuntansi 4, no. 2 (2017): 148-52.

${ }^{14}$ Ray Septianis Kartika, "Partisipasi masyarakat dalam mengelola Alokasi Dana Desa (ADD) di Desa Tegeswetan dan Desa Jangkrikan Kecamatan Kepil Kabupaten Wonosobo," Jurnal Bina Praja: Journal of Home Affairs Governance 4, no. 3 (2012): 179-88. 
pembangunan itu sendiri.

Visi dan Partisipasi inilah yang menjadi dua pokok penting yang disampaikan dalam Sarasehan Pemberdayaan Masyarakat yang diselenggarakan desa. Sarasehan ini dilakukan di Balai Desa Gogodeso yang dihadiri hampir seluruh elemen masyarakat desa seperti pelaku UMKM desa, tokoh masyarakat desa, seluruh perangkat desa termasuk dihadiri oleh Pejabat di lingkungan Badan Perencanaan Pembangunan Daerah dan Dinas Pertanian Kabupaten Blitar. Selain mereka agenda ini juga dihadiri oleh tim pengabdian Universitas Negeri Malang. Acara dibagi menjadi dua sesi besar. Sesi yang pertama disampaikan oleh perwakilan Bapeda dengan dihadiri langsung oleh Ketua Bapeda kabupaten Blitar. Pada penyampaiannya perwakilan dari pemerintah kabupaten ini menyatakan bahwa pemerintah terus mensupport dan mendorong pemerintah di level desa untuk mengembangkan sesuai dengan potensinya masing-masing. Pengembangan potensi desa sangat penting yang pada gilirannya akan menimbulkan multiplier effect bagi desa.

Sedangkan sesi kedua disampaikan oleh Kepala Desa Gogodeso Choirul Anam yang mengatakan mendorong sepenuhnya program penguatan UMKM. Bahkan pemerintah desa siap mendukung penguatan UMKM dengan bantuan kredit lunak yang tersedia di Lembaga Keuangan Mikro Badan Usaha Milik Desa (BUMDes) sebagai bagian dari income generating desa. Artinya bilamana UMKM makin berdaya saing dan terus maju maka akan berimplikasi pada pertumbuhan dan penguatan perekenomian desa. Kenapa? Karena dana yang dipinjam oleh UMKM potensial akan kembali lagi ke BUMDES ${ }^{15}$. Dana BUMDes akan dikelola kembali untuk kemaslahatan warga masyarakat dalam mengatasi kemiskinan. Sifat dana yang dipinjam juga bukan simpan pinjam dan kredit lunak, tetapi lebih pada modal bersama dan bagi hasil. Artinya diperlukan kejujuran dan integritas dari kedua belah pihak. Hal ini merupakan langkah kongkrit sekaligus terobosan dari desa untuk membangun branding Desa Wisata berbasis UMKM. Masih jarang ditemukan desa wisata yang fokus pada UMKM. Pemerintah desa Gogodeso juga mendobrak kelaziman pemerintah desa umumnya yang selama ini masih fokus pada pembangunan infrastruktur. Sarasehan ini seperti menjadi tonggak awal sejarah baru bahwa pemerintah desa akan fokus dalam pemberdayaan dan penguatan UMKM melalui BUMDES. Pada sesi berikutnya disampaikan oleh perwakilan dari tim Universitas Negeri Malang yang lebih menyoroti pada persoalan partisipasi aktif seluruh elemen warga dan visi bersama dalam membangun UMKM.

Di akhir sesi dilakukan penyebaran angket kepada seluruh peserta yang bersedia mengisi

15 Andrian Dolfriandra Huruta dan Gatot Sasongko, "Uang dan ruang yang berkelanjutan dalam pembentukan Badan Usaha Milik Desa (BUMDes)," Masyarakat, Kebudayaan dan Politik 29, no. 4 (2017): 212-22. 


\section{ENGAGEMENT}

Lurnal Pengabdian Kepada Masyarakat

ISSN : 2579-8375 (Print)

ISSN : 2579-8391 (Online)
This work is licensed under a Creative Commons Attribution-ShareAlike 4.0 International License.

CC BY SA

kuesioner (28 kuesioner) dengan hasil yang cukup menggembirakan meski ada dua peserta yang merasa pesimis (lihat diagram 1). Secara umum stakeholder terkait mengaku merasakan kegiatan ini secara keseluruhan bermanfaat bagi peserta dan mereka berusaha akan bersama-sama membangun desa melalui UMKM dengan support dari BUMDES melalui program pembiayaan.

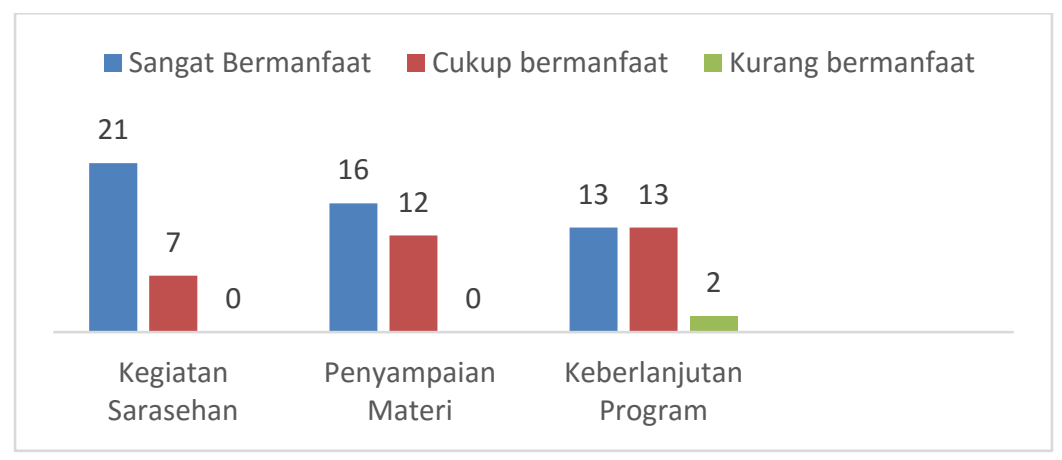

Diagram 1. Hasil Kuesioner Sarasehan Desa

\section{Desa dan Perguruan Tinggi membangun UMKM}

Masih cukup mengakar kuat paradigma pembangunan lama yakni "membangun desa" yang selalu menempatkan desa sebagai objek pembangunan ketimbang subjek pembangunan. Kebijakan pemerintah pusat sering mendistorsi peran pemerintah desa. Paradigma ini perlahan harus diubah melalui paradigma baru yaitu paradigma "desa membangun" yang mereposisi kedudukan desa. Bila paradigma ini diubah maka secara perlahan desa akan bertransformasi menjadi satu entitas yang kuat nan bermartabat berbasis kearifan lokal dan potensi yang dimiliki masing-masing desa. Kenapa ini penting? Pertama meski membangun desa bermakna pembangunan yang dilakukan di desa atau pembangunan pedesaan, tetapi praktik yang terjadi adalah justru pihak lain yang membangun desa. Bisa itu pemerintah daerah, pemerintah pusat hingga pihak ketiga yang seringkali ditempuh dengan cara intervensi ke dalam desa. Jika membangun desa bermakna negara hadir di depan, sebagai aktor utama yang membangun desa, maka desa membangun berarti pembangunan desa yang dimulai dari belakang ${ }^{16}$. Negara dalam hal ini pemerintah pusat dan daerah semestinya berdiri di belakang desa yang dalam bahasa Ki Hadjar Dewantara dikenal dengan tut wuri handayani. Dengan demikian desa membangun berarti desa mempunyai kemandirian dalam membangun dirinya (self-development). Kedua bila desa membangun dijadikan paradigma maka semestinya desa harus menjadi subjek, pondasi, basis dan arena dalam pembangunan bukan menjadi objek, lokasi, bahkan pesakitan pembangunan. Yang terakhir bila

\footnotetext{
${ }^{16}$ Robert Chambers, Y Sukoco, dan Robert Chambers, PRA: Participatory Rural Appraisal, Memahami Desa Secara Partisipatif (Walter de Gruyter, 1996).
} 


\section{ENGAGEMENT}

Lurnal Pengabdian Kepada Masyarakat

ISSN : 2579-8375 (Print)

ISSN : 2579-8391 (Online)
This work is licensed under a Creative Commons Attribution-ShareAlike 4.0 International License.

CC BY SA

desa membangun dilihat melalui perspektif sang aktor pembangunan maka sesungguhnya paradigma ini melahirkan ide pembangunan yang digerakkan, diberdayakan dan dikomandani oleh desa (village driven development/ VDD). Ide pembangunan ini mereposisi pembangunan yang digerakkan oleh masyarakat atau pihak ketiga lainnya yang dikenal dengan ide community-driven development (CDD). Artinya paradigma desa membangun merubah konstruksi dari CDD menjadi VDD.

Dalam pengabdian ini, pihak tim pengabdian Universitas Negeri Malang sepenuhnya mendampingi pihak desa dalam menguatkan UMKM Desa. Tujuannya agar diperoleh dua perspektif yaitu perspektif internal dari desa, dan perspektif eksternal dari Perguruan Tinggi. Kedua perspektif ini dibutuhkan dalam upaya memajukan UMKM. Tim pengabdian mencoba mendampingi pada bagaimana memasarkan produk UMKM tersebut agar bernilai tinggi dan juga layak jual. Bersama beberapa perwakilan UMKM yang ada, hasilnya disepakati untuk diadakan pelatihan dalam pemasaran melalui media sosial baik melalui facebook, instagram termasuk juga aplikasi whatsapp (lihat gambar 3).
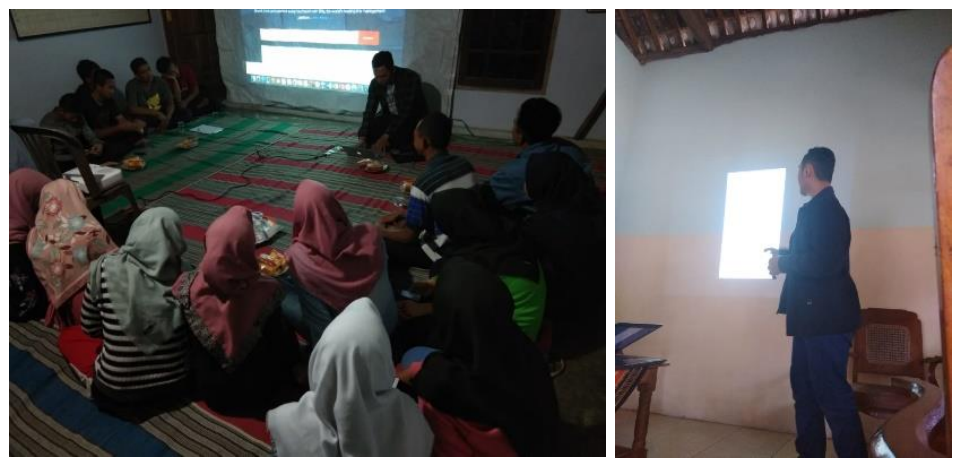

Gambar 3 Tahap Pelatihan Pemasaran melalui Media Sosial.

Pelatihan yang digelar ini membantu membangunkan kesadaran kritis kepada pelaku UMKM sekaligus memberikan pemahaman akan manfaat media sosial bagi pemasaran produk. Sekaligus di saat yang sama memberikan penjelesan bahwasanya media sosial menjadi salah satu sarana efektif dalam pemasaran dibandingkan dengan media konvensional lainnya. Selama ini pelaku UMKM masih melakukan penjualan secara konvensional dengan model gethok tular (words of mouth). Meski model ini baik, tetapi dampak luasan akan lebih mengena bila menggunakan media sosial termasuk ongkos promosi yang nyaris nol rupiah. Pelatihan ini sebagai langkah awal dalam mengenalkan media sosial pada pelaku UMKM di desa Gogodeso. Meski belum membuahkan hasil konkret, tetapi peserta mengafirmasi bahwa media sosial sangatlah penting dalam untuk meningkatkan penjualan sekaligus memperkenalkan produk mereka ke seantero negeri. Pada gilirannya akan berdampak pada desa Gogodeso itu sendiri.

Volume 3, Number 2, November 2019| 227

Desa Membangun UMKM: Pendampingan UMKM dalam Pembangunan Ekonomi Desa di desa Gogodeso Kabupaten Blitar

Luhung Achmad Perguna, Irawan, Imamul Huda Al Siddiq 
Pasca pelatihan yang dilakukan, pemerintah desa mulai menangkap arti penting akan penggunaan internet sebagai sarana pemasaran produk desa. Desa merespon dengan merilis website desa dengan alamat surel www.gogodeso-blitar.desa.id. Selain menginformasikan dan memberitakan tentang yang dilakukan desa Gogodeso, website ini juga memfasilitasi pelaku UMKM untuk memasarkan produknya melalui website ini. Hal ini merupakan terobosan yang dilakukan pemerintah desa atas dorongan dari pelaku UMKM dan tim pengabdian UM.

\section{Kesimpulan}

Program pengabdian masyarakat yang dilakukan di desa Gogodeso berusaha menjawab persoalan dalam UMKM utamanya dalam membangun visi desa wisata UMKM dan pemasaran UMKM. Langkah yang dilakukan tim pengabdian menjadi langkah awal dan tonggak sejarah baru arah pembangunan dan visi desa ke depan. Desa yang selama ini kehilangan arah, seperti menemukan kembali arah tujuannya. Sarasehan Desa Membangun juga menjadi angin segar bagi UMKM untuk mewujudkan UMKM yang lebih berdaya dengan bantuan keuangan dari Lembaga Keuangan Mikro yang ada di desa. Paradigma desa membangun terus dilembagakan ke masyarakat, karena sesungguhnya masyarakat desa lah subyek pembangunan sebenarnya. Pendampingan dalam pemasaran juga menjadi hal penting. Secara bertahap masyarakat mulai menggunakan pemasaran melalui website pasca pelatihan yang dilakukan. Pada akhirnya program ini membantu masyarakat Desa Gogodeso dalam upaya penguatan kelembagaan UMKM yang pada gilirannya akan mampu menjadikan warga desa menjadi lebih mandiri secara ekonomi dan sejahtera kehidupan warganya.

\section{Ucapan terima kasih}

Penulis mengucapkan terima kasih kepada Universitas Negeri Malang yang telah memberikan support atas terlaksananya kegiatan ini melalui dana pengabdian PNPB (Penerimaan Negara Bukan Pajak).

\section{Daftar Referensi}

Abdullah, Mohd Yusof Hj, Noor Rahamah Hj Abu Bakar, Junaenah Sulehan, Abd Hair Awang, dan Ong Puay Liu. "Participatory Rural Appraisal (PRA): An Analysis of Experience in Darmareja." Akademika 82, no. 1 (2012).

Berry, Albert, Edgard Rodriguez, dan Henry Sandee. "Small and medium enterprise dynamics in Indonesia." Bulletin of Indonesian Economic Studies 37, no. 3 (2001): 363-84.

Budiarto, Rachmawan, Susetyo Hario Putero, Hempri Suyatna, Puji Astuti, Harwin Saptoadi, M 


\section{ENGAGEMENT}

Lurnal Pengabdian Kepada Masyarakat

ISSN : 2579-8375 (Print)

ISSN : 2579-8391 (Online)
This work is licensed under a Creative Commons Attribution-ShareAlike 4.0 International License. CC BY SA

Munif Ridwan, dan Bambang Susilo. Pengembangan UMKM Antara Konseptual dan Pengalaman Praktis. UGM Press, 2018.

Chambers, Robert. "The Origins and Practice of Participatory Rural Appraisal." World development 22, no. 7 (1994): 953-969.

Chambers, Robert, Y Sukoco, dan Robert Chambers. PRA: Participatory Rural Appraisal, Memahami Desa Secara Partisipatif. Walter de Gruyter, 1996.

FN, Ainna Amalia, dan Lilis Rahmawati. "Pendampingan Manajemen Keuangan Melalui Program Literasi Keuangan Kepada Komunitas Usaha Mikro Kecil dan Menengah (UMKM) yang Terjerat Rentenir di Kabupaten Nganjuk." Engagement : Jurnal Pengabdian Kepada Masyarakat 3, no. 1 SE-Articles (30 Mei 2019). https://doi.org/10.29062/engagement.v3i1.55.

Hasbullah, Rokhani, Memen Surahman, Ahmad Yani, Deva Primadia Almada, dan Elisa Nur Faizaty. "Model pendampingan UMKM pangan melalui inkubator bisnis perguruan tinggi." Jurnal Ilmu Pertanian Indonesia 19, no. 1 (2014): 43-49.

Huruta, Andrian Dolfriandra, dan Gatot Sasongko. "Uang dan ruang yang berkelanjutan dalam pembentukan Badan Usaha Milik Desa (BUMDes)." Masyarakat, Kebudayaan dan Politik 29, no. 4 (2017): 212-22.

Kartika, Ray Septianis. "Partisipasi masyarakat dalam mengelola Alokasi Dana Desa (ADD) di Desa Tegeswetan dan Desa Jangkrikan Kecamatan Kepil Kabupaten Wonosobo.” Jurnal Bina Praja: Journal of Home Affairs Governance 4, no. 3 (2012): 179-88.

Narayanasamy, Nammmalvar. Participatory rural appraisal: Principles, methods and application. SAGE Publications India, 2009.

Prasetyo, P. Eko. "Peran Usaha Mikro Kecil Dan Menengah (UMKM) Dalam Kebijakan Penanggulangan Kemiskinan Dan Pengangguran.” Akmenika Upy 2, no. 1 (2008): p1-13.

Rozaki, Abdur, dan Siti Rohaya. "Memberdayakan Desa Melalui Pariwisata Berbasis BUMDES ." Engagement : Jurnal Pengabdian Kepada Masyarakat 3, no. 1 SE-Articles (30 Mei 2019). https://doi.org/10.29062/engagement.v3i1.46.

Soedarwo, Vina Salviana Darvina. "Pemberdayaan Masyarakat Melalui Pendidikan Nonformal Berbasis Potensi Lokal dalam Membangun Desa Wisata Adat.” Jurnal Sosiologi Pendidikan Humanis 2, no. 2 (2017): 96-102.

Sudaryanto, Ragimun, dan Rahma Rina Wijayanti. "Strategi Pemberdayaan Umkm Menghadapi Pasar Bebas Asean.” Pusat Kebijakan Ekonomi Makro. Badan Kebijakan Fiskal. Kementerian Keuangan, Jakarta, 2013.

Tulus, Tahi Hamonangan Tambunan. "Development of small and medium enterprises in a developing country." Disunting oleh Kevin McKague, David Wheeler, Corrine Cash, Jane Comeault, dan Elise Ray. Journal of Enterprising Communities: People and Places in the Global Economy 5, no. 1 (1 Januari 2011): 68-82. https://doi.org/10.1108/17506201111119626.

Wida, Siti Ainul, Djoko Supatmoko, dan Taufik Kurrohman. "Akuntabilitas Pengelolaan Alokasi 
ENGAGEMENT

Lurnal Pengabdian Kepada Masyarakat ISSN : 2579-8375 (Print) ISSN : 2579-8391 (Online)
This work is licensed under a Creative Commons Attribution-ShareAlike 4.0 International License. CC BY SA

Dana Desa (ADD) di Desa-Desa Kecamatan Rogojampi Kabupaten Banyuwangi.” EJournal Ekonomi Bisnis Dan Akuntansi 4, no. 2 (2017): 148-52. 